\title{
Traditional Use of Herbal Remedies in Livestock by Farmers in 3 Swiss Cantons (Aargau, Zurich, Schaffhausen)
}

\author{
Kathrin Schmid ${ }^{\mathrm{a}}$ Silvia Ivemeyer ${ }^{\mathrm{b}} \quad$ Christian Vogl $^{\mathrm{c}} \quad$ Franziska Klarer $^{\mathrm{d}}$ \\ Beat Meier $^{\mathrm{d}} \quad$ Matthias Hamburger $^{\mathrm{a}} \quad$ Michael Walkenhorst $^{\mathrm{b}}$
}

\footnotetext{
${ }^{a}$ Institute of Pharmacentical Biology, Department of Pharmaceutical Sciences, University of Basel,

${ }^{\mathrm{b}}$ Research Group 'Animal Health Division', Research Institute of Organic Agriculture, Frick, Switzerland

${ }^{c}$ Division of Organic Farming, Department of Sustainable Agricultural Systems, University of Natural Resources and Life Sciences,

Vienna, Austria

d Unit of Phytopharmacy, Institute of Biotechnology, Zurich University of Applied Sciences, Wädenswil, Switzerland
}

\section{Keywords}

Ethnoveterinary medicine $\cdot$ Medicinal plants · Organic agriculture $\cdot$ Switzerland · Aargau, Zurich, Schaffhausen

\section{Summary}

Background: This study investigated the extent of traditional knowledge and use of homemade herbal remedies for livestock by farmers in 3 Swiss cantons (Aargau, Zurich, Schaffhausen). The study focused on organic farms. Methods: At 21 farms, 24 farmers aged 36-83 years were interviewed with a semi-structured, detailed questionnaire. For each homemade herbal remedy, the plant species, mode of preparation, source of knowledge, and application were gathered. Satisfaction of the farmers with the application was estimated with the aid of a visual analogue scale. Results: Information on a total of 165 homemade remedies was collected of which 123 contained a single plant species only (homemade mono-species herbal remedies, HMHR). The $123 \mathrm{HMHR}$ were selected for this paper. They corresponded to 150 different applications and originated from 43 plant species from 30 families. Plants belonging to the families of Asteraceae, Lamiaceae, and Apiaceae were used most frequently. The single most applied species were Matricaria recutita L., Calendula officinalis L., Symphytum officinale L., and Coffea arabica L. For each formulation, 1-4 different applications were mentioned, most of them for cattle. The main applications are related to a) skin alterations and sores, b) gastrointestinal and metabolic diseases as well as c) infertility and diseases of the female genitalia. Approximately half of the applications were used during the last 12 months prior to the interview. Conclusion: This study shows that HMHR are used by Swiss farmers for the treatment of different livestock diseases. In general, the farmers were satisfied with the outcome of the applications.

\section{Schlüsselwörter}

Ethnoveterinärmedizin · Arzneipflanzen · Biologischer Landbau * Schweiz · Aargau, Zürich, Schaffhausen

\section{Zusammenfassung}

Hintergrund: Diese Studie untersucht, inwieweit traditionelles Erfahrungswissen über Arzneipflanzenanwendungen beim Nutztier auf landwirtschaftlichen Betrieben dreier Schweizer Kantone (Aargau, Zürich, Schaffhausen) vorhanden ist und angewendet wird. Im Studienfokus lagen Biobetriebe. Methoden: In 21 Betrieben wurden 24 Landwirtinnen und Landwirte im Alter von 36 bis 83 Jahren anhand eines semistrukturierten, detaillierten Fragenkatalogs befragt. Für jede genannte Rezeptur wurden Informationen zu Pflanze, Herstellungsprozess, Wissensursprung und Anwendung dokumentiert. Ihre Zufriedenheit mit der Wirkung bewerteten die Landwirtinnen und Landwirte anhand einer visuellen Analogskala (VAS). Ergebnisse: Insgesamt wurden 165 Rezepturen erfasst. Davon enthielten 123 Rezepturen als Bestandteil je eine einzelne Pflanzenart. Nur diese 123 Rezepturen und ihre insgesamt 150 Anwendungen wurden näher betrachtet. Insgesamt 43 Pflanzenarten aus 30 Familien kamen zum Einsatz. Die Pflanzenfamilien Asteracae, Lamiaceae und Apiaceae waren am häufigsten in den Rezepturen vertreten. Die Pflanzenarten Matricaria recutita L., Calendula officinalis L., Symphytum officinale L. und Coffea arabica L. wurden am häufigsten angewendet. Für jede Rezeptur wurden bis zu 4 verschiedene Anwendungen, überwiegend für Rinder, beschrieben. Die häufigsten Anwendungsgebiete waren a) Hautveränderungen und Wunden, b) Erkrankungen des Magen-Darm-Trakts und Stoffwechselstörungen sowie c) Fruchtbarkeitsstörungen und Erkrankungen der weiblichen Genitale. Rund die Hälfte der Rezepturen wurde während der letzten 12 Monate vor dem Erhebungsdatum angewendet. Basierend auf der Auswertung der VAS zeigten sich die Landwirtinnen und Landwirte mit dem Ergebnis der Anwendung zufrieden. Schlussfolgerung: Diese Studie zeigt, dass pflanzliche Rezepturen von Schweizer Landwirtinnen und Landwirten zur Behandlung ihrer Nutztiere mit großer Zufriedenheit eingesetzt werden.

\section{KARGER \\ Fax +497614520714 \\ Information@Karger.de}

www.karger.com (c) 2012 S. Karger GmbH, Freibur

$1661-4119 / 12 / 0193-0125 \$ 38.00 / 0$

Accessible online at:

www.karger.com/fok
Michael Walkenhorst

Forschungsinstitut für Biologischen Landbau

Ackerstrasse, Postfach, 5070 Frick, Switzerland

Tel. +41 $6286572-86$, Fax -73

michael.walkenhorst@fibl.org 


\section{Introduction}

Ethnoveterinary research is defined as 'the systematic investigation and application of folk veterinary knowledge, theory and practice' [1]. The World Health Organisation defines the use of traditional medicine as 'the sum total of knowledge, skills and practices based on the theories, beliefs and experiences indigenous to different cultures that are used to maintain health, as well as to prevent, diagnose, improve or treat physical and mental illnesses' [2]. In former times, knowledge on medicinal plants was passed down from generation to generation. In modern societies such as those of Western Europe, traditional knowledge is in danger of disappearing [3]. Most ethnoveterinary surveys on the preparation and utilization of herbal remedies have been conducted in Africa, Asia, and Latin America [4]. In these countries, access to conventional drugs is more difficult, and they are hence dependent on the use of homemade preparations [5]. Nonetheless, in Europe, particularly in Mediterranean regions and in specific areas of Austria, surveys on the usage of traditional medicinal plants to treat livestock have been conducted [6-15]. However, in Switzerland, no comparative surveys regarding the use of homemade herbal remedies by Swiss farmers have been carried out, except for 1 survey in Safiental, a region of the Canton Graubünden with approximately 1,000 inhabitants [16].

The European Council Regulations on Organic Farming (nos. 834/2007 and 889/2008) and the Swiss Regulation of Organic Agriculture require a preference to veterinary complementary medicine, such as the use of phytotherapeutic products, for the treatment of livestock diseases. Chemically synthesized allopathic veterinary medicinal products including antibiotics should only be used under strict conditions $[17,18]$. However, the required treatment of certain animal species with veterinary complementary medicines is hampered by for example the limited number of such substances commercially available and registered in the Swiss 'Tierarzneimittelkompendium' (veterinary formulary) [19]. Therefore, organic farmers in particular use homemade herbal remedies to treat their animals, which are often based on traditional formulations handed down over generations.

There is an increasing consumers' demand for high-quality animal food products with no or limited use of pharmaceuticals produced on a chemical or biotechnological basis [4].

The aim of this paper is to analyze the current knowledge and usage of medicinal plants by farmers in the 3 Swiss cantons of Aargau, Zurich, and Schaffhausen with the main focus on organic farms. We want to compare our results with ethnoveterinary literature from Europe to differentiate between regional specialities and supraregional equalities, as well as with the pharmacological literature, gaining a first impression of the potential efficacy of homemade herbal remedies.

\section{Methods}

Study Region

The survey was conducted in 3 of 26 Swiss cantons, namely Aargau, $\mathrm{Zu}$ rich, and Schaffhausen. The 3 contiguous cantons have a common border to Germany in the north and are situated between $8^{\circ} 04^{\circ}-8^{\circ} 65^{\circ} \mathrm{E}$ and $47^{\circ} 34^{\prime}-47^{\circ} 71^{\prime} \mathrm{N}$. They cover an area of $3,431 \mathrm{~km}^{2}$ with a total population of 2.1 million. The altitude varies between 330 and 1,292 $\mathrm{m}$ above sea level. The average annual temperature is $8.6^{\circ} \mathrm{C}$, and annual precipitation averages $1,021 \mathrm{~mm}$. In 2009, there were a total of 8,567 farms in the 3 cantons. In Zurich 318 out of 4,028 (8\%), in Aargau 204 out of $3,864(5.5 \%)$, and in Schaffhausen 20 out of $675(3 \%)$ were organic farms. Of the 542 organic farms, 410 kept cattle $(75.6 \%)$ and $55 \mathrm{kept}$ pigs $(10.1 \%)$ [20].

\section{Farm Sampling Method}

All organic farmers of the 3 cantons were invited by letter to participate in the project. 7 farmers responded spontaneously. The 40 farmers from Aargau, Zurich, and Schaffhausen of the Organic Dairy Farm Research Network (ODRN; Research Institute of Organic Agriculture) as well as the 14 members (2010) of the Workgroups of Complementary Medicine in Zurich and Schaffhausen (WGCM) were contacted and invited by telephone, which lead to 9 participants. A further 5 dialog partners could be found with the snowball sampling method [21] through reactions to the letter or information provided by farmers of the ODNR and WGCM. All dialog partners met the following criteria: 1) naming of at least 3 homemade herbal remedies during the first contact via telephone; 2) willingness to talk about their knowledge and to communicate it to a third party; 3 ) inclusion of respondents irrespective of farm type (organic or integrated production), or sex and age of the interviewee.

\section{Farms and Farmers}

A total of 21 interviews with 24 farmers were carried out. At 3 farms, couples were interviewed together upon request of the respondents, and the answers per couple were merged into 1 interview. The interview sample comprised 12 women and 12 men between the age of 36 and 83 years ( $53 \pm 13$ years) from 17 organic farms and 4 farms with integrated production. 12 interviews were held in canton Aargau, 8 in Zurich, and 1 in Schaffhausen. There were a total of 20 cattle farms of which 13 were dairy farms and 7 suckler cow husbandries. 1 horse range was included. In addition, 12 of the farms had laying hens, 6 had pigs, 5 had horses and sheep, and 2 grew broilers. The dairy farms had between 10 and 120 cattle. The smallest suckler cow husbandry had just 1 , and the biggest 50 cattle. The agricultural production land, together with the rotation farming area, was between 5 and 138 ha.

\section{Interview Structure}

At the beginning of the interview, the respondents were asked to give written consent for the recording of the subsequent dialogue (recorded with OLYMPUS WS 200S Digital Voice Recorder, Olympus Imaging Europa GmbH, Dortmund, Germany). The recordings were not transcribed but served as a backup source in the case of uncertainties in the data analysis of each interview. The interviews were structured into 3 parts: 1) general information about the farm; 2) semi-structured conversation-guide based on different verbalizations of 7 'free listing' questions [21, 22]; and 3) questionnaire to get differentiated information about the specific homemade herbal remedies and their application and administration. An entire interview took between 1.5 and $3.5 \mathrm{~h}$. The aim of the 'free listing' part was to generate an informal and pleasant atmosphere for the farmers where they could talk freely. Furthermore, this part was done to obtain first information about medicinal plants and formulations known by the farmers. The first 2 parts together usually took 30-60 min. The third part of the interview was a questionnaire about farm-specific homemade remedies with 1 or more applications as 
applied by the farmers, containing either pre-coded or free answer possibilities. All data was subsequently entered into a Microsoft Access database [23].

\section{Remedies and Applications}

The German name of the plant was asked and, if necessary, pictures or books were used to define the botanical name. Information on the manufacturing process of the homemade herbal remedies was gathered, including the extraction process and the type of ointment. The manufacturing processes were not witnessed personally. The application of every remedy was asked. The respondent could give a free answer which was coded in categories of use. Route and frequency of administration and duration of the therapy were further registered issues. Daily dosages of oral adminis trations were determined by weighing the medicinal plants on site. If this was not possible, the weight of daily dosages was estimated by assessment of the administered volume of a herb and subsequent weighing, or by personal assessments by the farmers. The daily dosage was calculated for all medicinal plants for which more than 2 applications for oral administration were reported. To achieve a common basis for comparison between different species including humans, daily dosages were normalized by taking into account the different weight of the species by conversion of all dosages in dosage per kilogram metabolic body weight $(\mathrm{MBW}=$ body weight ${ }^{0.75}$ ) [24] according to the following formula:

daily dose $\left(\frac{\mathrm{g}}{\mathrm{kg}^{0,75}}\right)=\frac{\text { drug dose per administration }(\mathrm{g}) \times \text { repetition per day }}{\text { metabolic body weight }\left(\mathrm{kg}^{0,75}\right)}$

MBW was calculated with the following live weight: an adult cow or horse with $650 \mathrm{~kg}\left(\mathrm{MBW}=128.7 \mathrm{~kg}^{0.75}\right)$, a calf with $75 \mathrm{~kg}\left(\mathrm{MBW}=25.5 \mathrm{~kg}^{0.75}\right)$, a young pig with $15 \mathrm{~kg}\left(\mathrm{MBW}=7.6 \mathrm{~kg}^{0.75}\right)$, a hen with $1 \mathrm{~kg}(\mathrm{MBW}=$ $\left.1 \mathrm{~kg}^{0.75}\right)$, and a human with $65 \mathrm{~kg}\left(\mathrm{MBW}=22.9 \mathrm{~kg}^{0.75}\right)$. If the respondents used the same daily oral dosage for calves and adult cattle, values for both age brackets were calculated. The sources of knowledge for homemade herbal remedies were gathered as well as the frequency of use and the date of the last use. Satisfaction with each application of homemade herbal remedies was assessed with a visual analogue scale (VAS) as a practical, reliable, and valid measurement [25]. In this study, this refers always to the farmer who mentioned the formulation with the corre sponding application, and was estimated by the farmer when a homemade herbal remedy had been used twice or more. Respondents could decide on a scale of $100 \mathrm{~mm}$ between the endpoints 'no effect' $(0 \mathrm{~mm})$ and 'very good effect' $(100 \mathrm{~mm})$. For each category of use, the arithmetic mean and standard error of the VAS values were determined.

\section{Results}

In total, 165 homemade remedies were mentioned and described by the interview partners. This number includes 123 homemade mono-species herbal remedies (HMHR) with only 1 plant species each with or without extraction, 11 homemade composed herbal remedies with a maximum of 12 plant species, and 31 homemade remedies without plant species but containing 1 or more natural products such as curds, honey, vinegar, salt, or cod liver oil. The interview partners characterized between 2 and 14 homemade remedies per farm (mean $7.9 \pm 3.2$ ) and mentioned between 1 and 4 different applications for each homemade remedy (mean $1.2 \pm 0.5$ ). The homemade herbal remedies included a total of 65 plant species belonging to 42 families.

\section{Ingredients and Formulation of 123 HMHR}

In this paper, we present only the $123 \mathrm{HMHR}$ which included a total of 43 plant species belonging to 30 families and were used to treat cattle, horses, sheep, goats, pigs, hens, and cats. The 3 plant families mentioned in most HMHR were Asteraceae $(27,22.0 \%)$, Lamiaceae $(13,10.7 \%)$, and Apiaceae (10, $8.1 \%$ ) (table 1). The most widely used plant species was Matricaria recutita L. used in 14 of the 123 HMHR (11.4\%), followed by Calendula officinalis L., Symphytum officinale L., and Coffea arabica L. (each with 9 HMHR, 7.3\%) (table 1). Different plant parts were used in the HMHR with seeds and fruit being the most common category (33 HMHR, 26.8\%), followed by flowers, whole plants without roots (herb), leaves, roots, and twigs. Dried herbals drugs were used in $48.8 \%$ of the HMHR, while fresh plants were either administered directly or further processed in $43.1 \%$ of the HMHR. 6 commercial products were used in $10 \mathrm{HMHR}$ (8.1\%): Kamil$\operatorname{losan}^{\circledR}$ (MEDA Pharma GmbH \& Co. KG, Bad Homburg, Germany), WELEDA Arnica Tincture ${ }^{\circledR}$ (Weleda AG, Arlesheim, Switzerland), WELEDA Calendula Tincture ${ }^{\circledR}$ (Weleda), thyme oil, eucalyptus oil, and NJP Liniment ${ }^{\circledR}$ (Casa Verde Naturprodukte Vertriebs GmbH, Dortmund, Germany; including oil of Mentha arvensis L. var. piperascens). Besides the 6 directly used commercial products $(4.8 \%)$, in 35 HMHR $(28.5 \%)$ fresh or dried plant parts were directly used without further formulation or extraction. As solvent for extraction, water was used in 52 HMHR (42.3\%), mainly for external or oral administration. These aqueous extractions were mainly (45 HMHR) infusions, and in 7 HMHR decoctions. Extraction with alcohol (schnapps) at room temperature was used in 14 HMHR (11.4\%). The used schnapps contained between 40 and $90 \%$ ethanol. Further extraction with oil or fat at room temperature was reported in $8 \mathrm{HMHR}$ $(6.5 \%)$, and extraction with lipids at elevated temperature was described in $7 \mathrm{HMHR}$ (5.7\%). $1 \mathrm{HMHR}$ was extracted with cider vinegar $(0.8 \%)$ (table 1$)$. A total of 12 ointments were prepared from 5 fresh or dried medicinal plant species. Beeswax was used as ointment base in 8 cases, whereas in 4 formulations the ointment base served directly as extractant.

\section{Applications of the $123 \mathrm{HMHR}$}

A total of 150 applications were named for the $123 \mathrm{HMHR}$. The main areas of application were 1) skin alteration and sores, 2) gastrointestinal diseases and metabolic dysfunction, 3 ) infertility and diseases of the female genitalia, 4) mastitis, 5 ) internal injuries, and 6) respiratory tract diseases (table 2). The most frequently named plant for the treatment of skin alterations and sores was Matricaria recutita L. (18 applications), followed by Calendula officinalis L. (9 applications) and Rhamnus catharticus L. (7 applications). For the treatment of gastrointestinal diseases and metabolic dysfunc- 


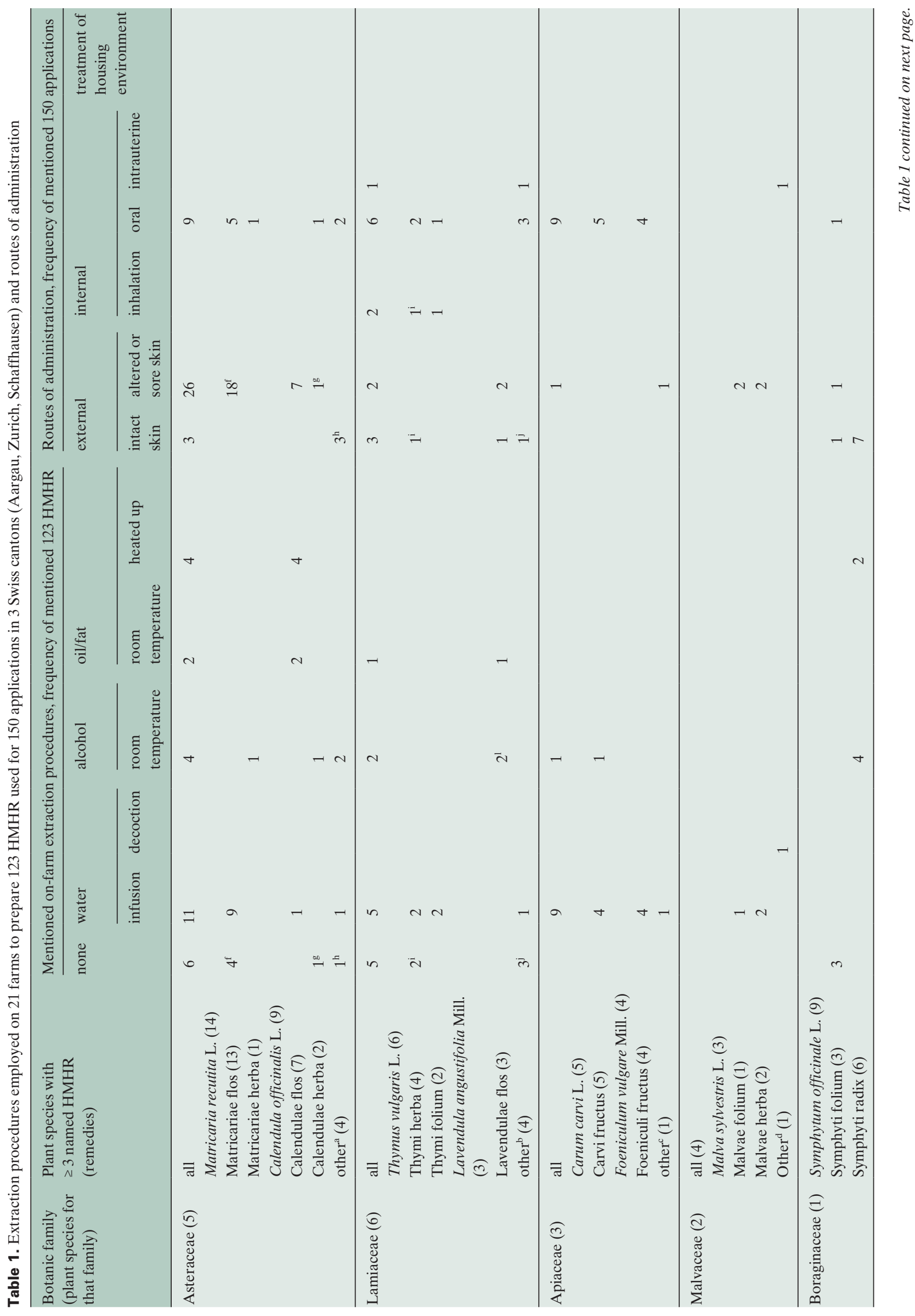




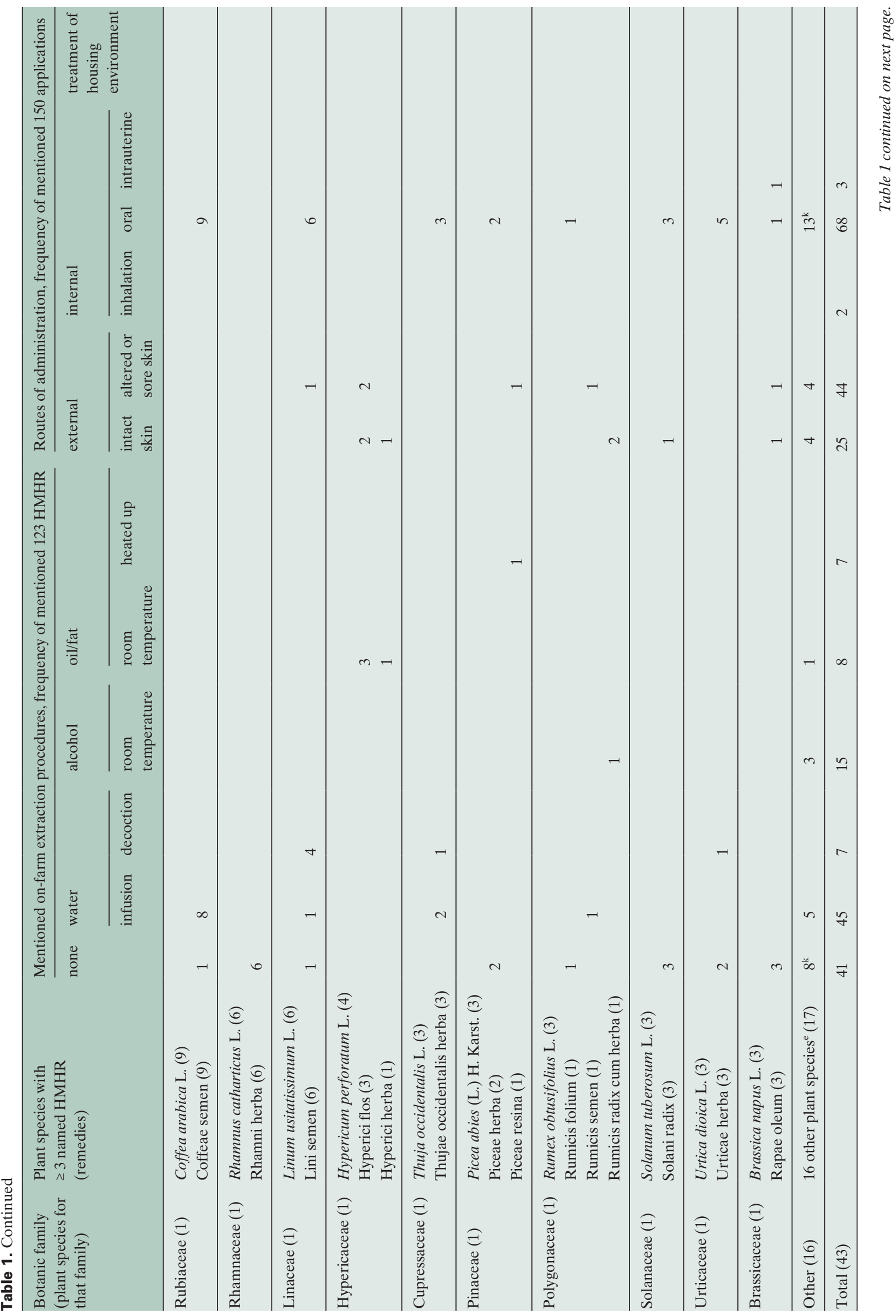




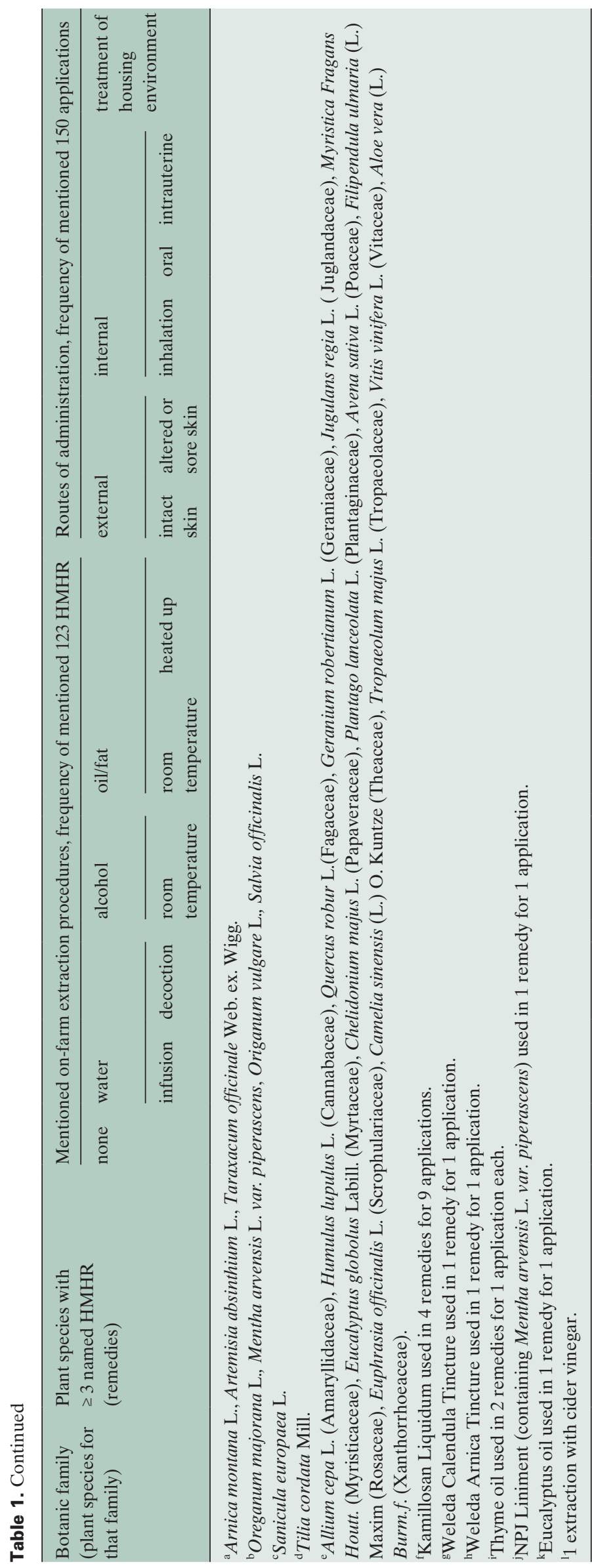

tions, Matricaria recutita L. (6 applications) and Coffea arabica L. (8 applications, 6 times in addition to schnapps) were used. For treatment of infertility, the farmers most often used Thuja occidentalis L. (3 applications). The HMHR were mostly used to treat cattle (118 applications, 78.7\%), followed by horses (20 applications, $13.3 \%$ ) and other animals (12 applications, 8.0\%). Oral administration was most frequently used (68 applications, $45.3 \%$ ) (table 1), e.g. for the treatment of diarrhea, stomach trouble, indigestion, cough, pneumonia, or uterine inflammation. For oral administration, the plant was often applied directly or as an extract made with water or alcohol. Orally administrated HMHR were either added to the feedstuff or applied by enforced administration. External administration on altered and sore skin, claws, hooves, and eyes was used in 44 applications $(29.3 \%)$. For treatment of wounds, farmers used HMHR as baths, washes or compresses, or simply as a direct application of the oil or ointment to the lesion. For treatment of irritated eyes, the respondents used washouts with water extractions. Administration on intact skin was reported in 25 applications $(16.7 \%)$ to treat internal injuries like pulled or hardened muscles, contusions, sprains, and swellings, or as repeller against ectoparasites. Usually, the farmers rubbed oil or ointment formulation on the affected body parts. 3 applications were intrauterine administrations, either to prevent inflammation or for cleaning the uterus after calving. 2 applications were used for inhalation (table 2). A special administration is linked to the use of Rhamnus catharticus L. to treat cattle ringworm. The twigs were not administered or applied onto the animals but were hung up in the stable for 8 weeks up to 1 year. In 4 applications, the farmers used Rhamnus catharticus L. therapeutically and in 3 applications prophylactically (table 2). The applications were used in 72 cases $(48.0 \%)$ during the last 12 months and in 15 cases $(10.0 \%)$ in the last few days preceding the interviews. The HMHR were used in pure form in most applications. 52 applications $(34.7 \%)$ were used in combination with other homemade or homeopathic remedies. The use of 25 applications $(16.7 \%)$ was, in the case of aggravation, combined with veterinary treatments, mainly for rehydration during diarrhea therapy. More than half of the applications were employed by the respondents more than 10 times (83 applications, 55.3\%), 51 applications between 2 and 10 times (34.0\%), and 16 applications less than 2 times (10.7\%). The knowledge on the use of these applications was obtained from the forefathers (57 applications, 38.0\%), books (29 applications, $19.3 \%$ ), own experience (20 applications, $13.3 \%$ ), friends (14 applications, 9.3\%), and other sources such as newspapers (30 applications, 20.0\%). With the help of a VAS, the degree of satisfaction with the 123 applications in which the HMHR were applied 2 or more times was evaluated for the pure use. Overall, the farmers were satisfied with the efficacy of their plant preparations (fig. 1). 


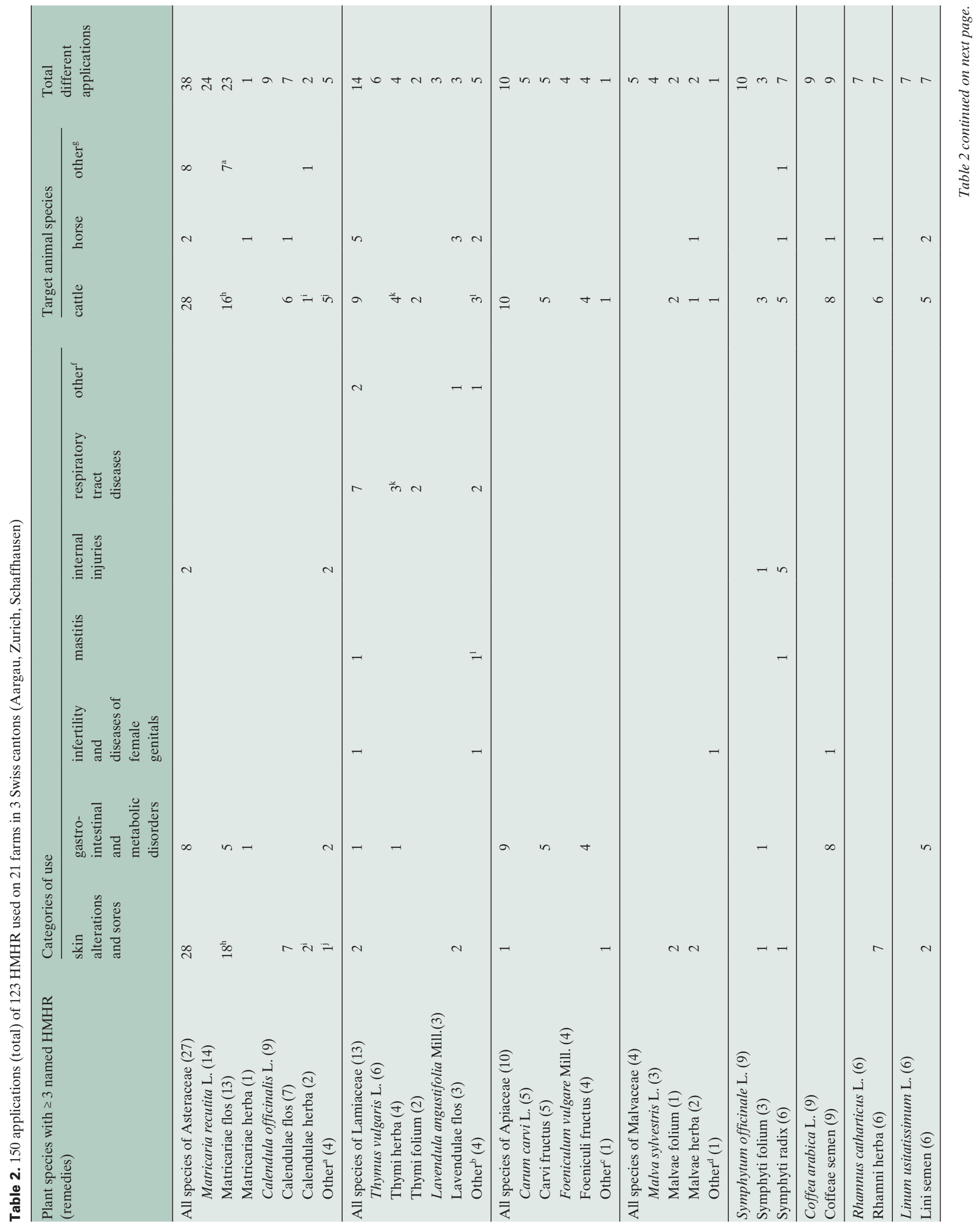




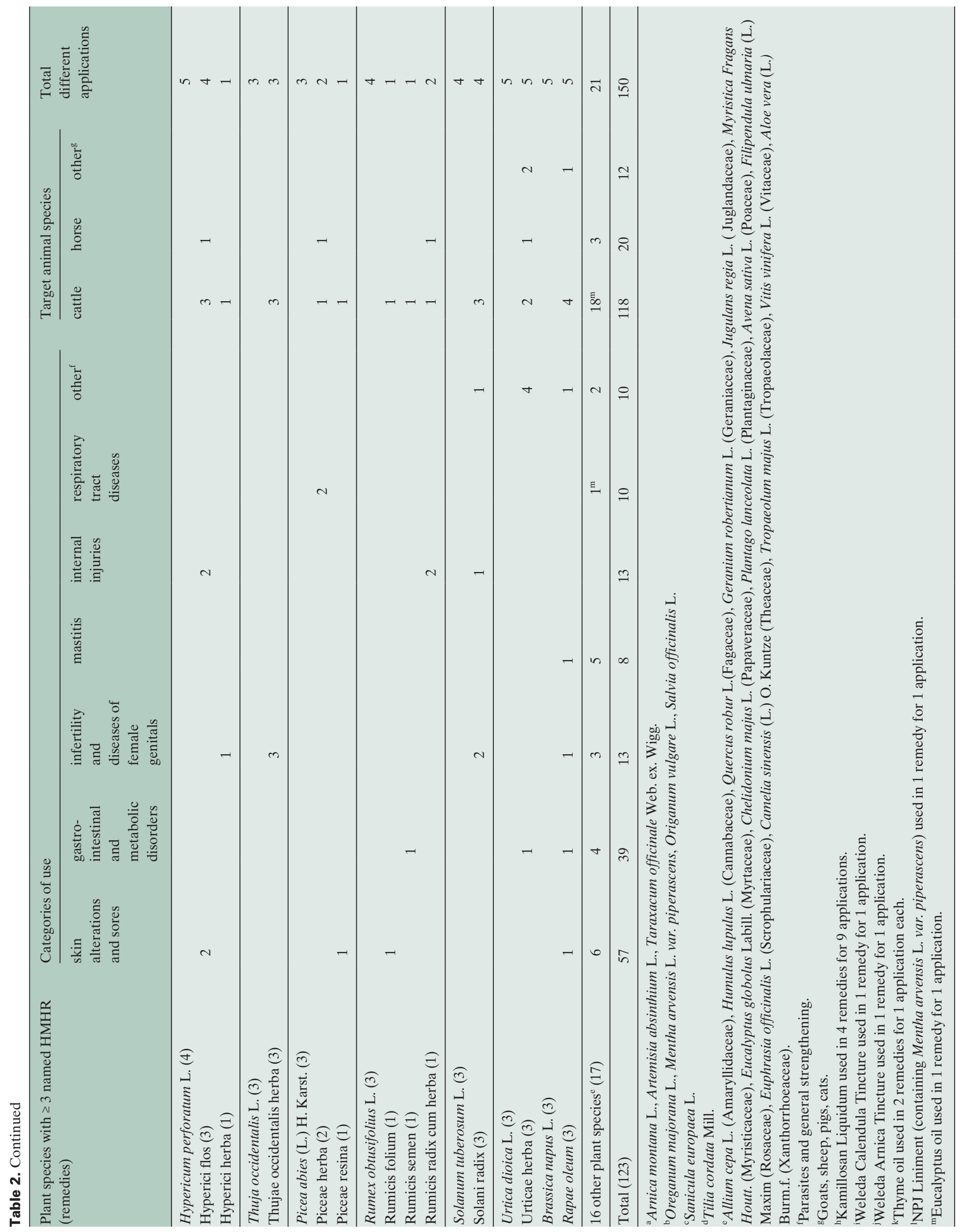




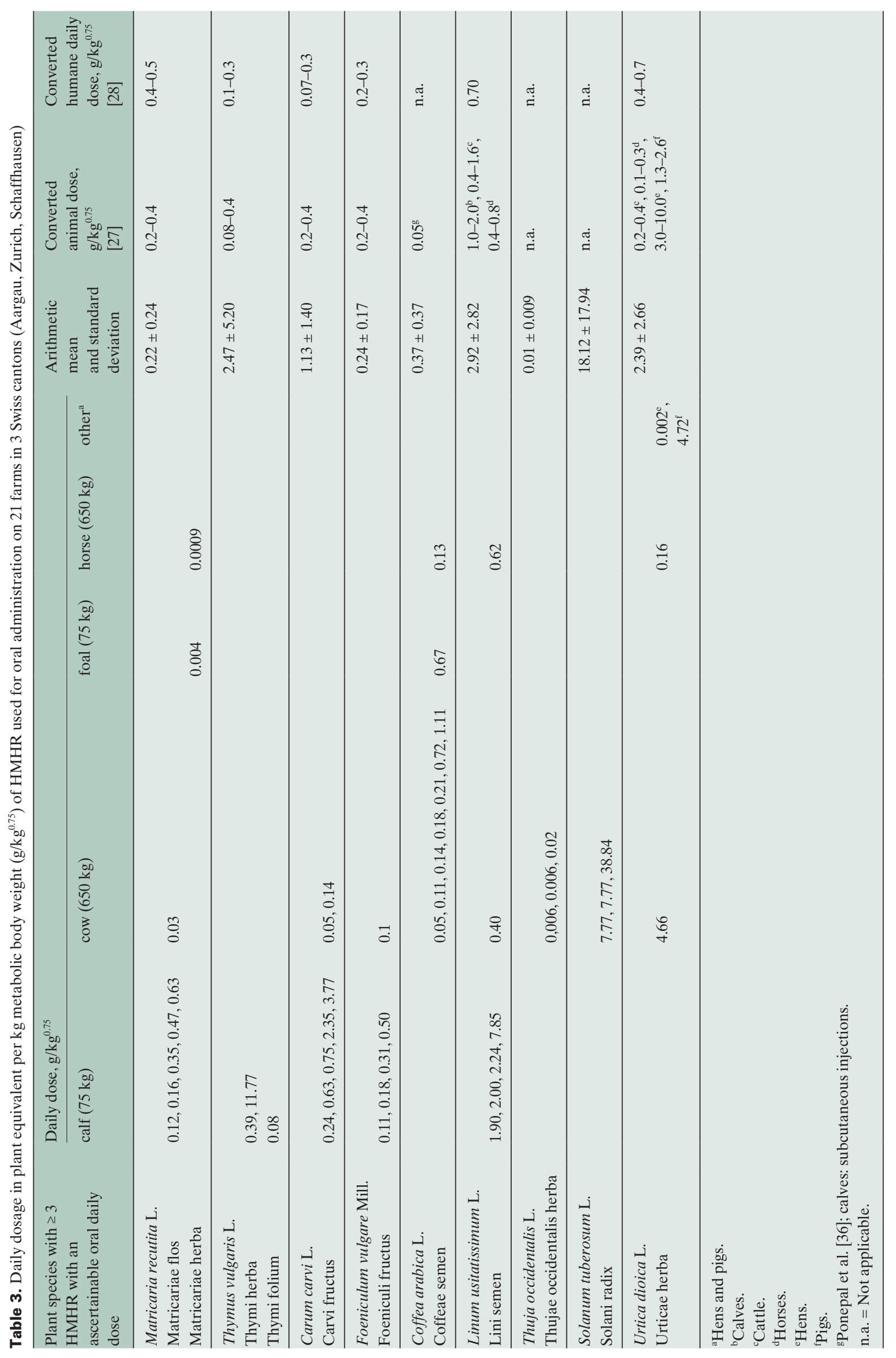




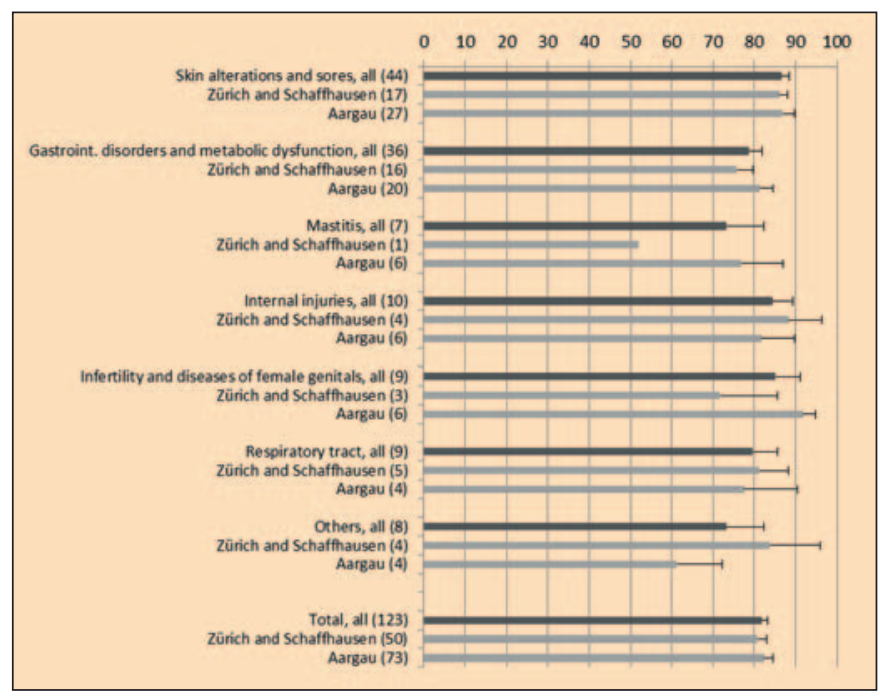

Fig. 1. Degree of satisfaction of farmers with the outcome of the 123 applications used twice or more, as estimated on a $100 \mathrm{~mm}$ VAS (arithmetic mean and standard error; numbers in brackets indicate the frequency with which application was mentioned).

\section{Discussion}

The present study was the first survey on the knowledge and use of homemade herbal remedies by farmers in the Northern part of Switzerland. Organic farms were chosen as focus group because we supposed that these farms may need to be knowledgeable about herbal remedies which is the required treatment method according to the Swiss Organic Regulation [18]. The farms producing according to integrated production, which were obtained by the snowball sampling method, [21] also feature traditional knowledge although the results cannot be considered as representative. However, the chosen sampling method is common in studies gathering information on traditional knowledge $[6,9,11-13,16]$. The farmers used homemade herbal remedies as first measure to treat mild or moderate diseases. The dosages assessed in the interviews have to be considered as approximations. However, this enabled us to compare them with dose recommendations in the literature (table 3). Such comparisons have not been reported in similar surveys from other European countries [9-16]. The range of reported dosages was wide. This may be explained by the high therapeutic index of most herbal drugs. The success estimations on VAS by the interviewed farmers was certainly subjective, but was a general indicator for their degree of satisfaction with the results of their treatments. The majority of documented applications were for cattle. This can be attributed to the fact that $95 \%$ of the participating farms kept dairy or suckler cows. In the organic farms of the investigated area, cattle were the most important farm animal species [20]. In the 3 investigated cantons, as well as in different Austrian regions and in Swiss Safiental, the farmers most frequently used Matricaria recutita L., Calendula officinalis L., and Coffea ara- bica L. In Austria as well as in Swiss Safiental, Arnica montana L. was more often used than in our study. This may be ascribed to the fact that these surveys focused on the alpine regions where Arnica grows naturally and thus is known better to local farmers $[6,9,11,16]$. In Austria and Switzerland, the most widely used herbal drugs were employed for similar indications. In our survey, we recorded more frequent usage of fruits from the family of Apiaceae, such as cumin and caraway, for treating gastrointestinal disorders than reported in the Austrian studies $[6,9,11-13]$. The 8 most relevant medicinal plants which were used for more than 4 homemade herbal remedies each are briefly discussed in the following with a focus on categories of use and dosage in the case of orally administrated applications.

\section{Chamomile Flowerheads (Matricaria recutita $L$.,}

\section{Matricariae flos)}

Chamomile was administered internally and externally and used to treat gastrointestinal diseases and skin alterations and sores. These findings are in line with ethnoveterinary studies in Swiss Safiental, Austria, and Western Spain [6, 7, 9, 11-13, 16]. However, use of chamomile was not documented in surveys in Catalonia and Tuscany $[8,26]$. The treatment of gastrointestinal disorders, metabolic dysfunctions, and skin alterations and sores is also described in veterinary medicine [27], and is supported by in vitro and in vivo pharmacological studies on major constituents [28] and chamomile extracts $[29,30]$. Dosages described for oral administration were, on average, comparable to recommendations for veterinary use [27], and in the range of human doses (table 3) [28]. Kamillosan was the only commercial chamomile product that was used as ingredient in several formulations. It is also used by the Department for Livestock of the Veterinary Clinic Zurich for the treatment of sores and in inhalations against pneumonia (table 3) (Prof. Dr. Ueli Braun, Zurich, Personal Communication) .

\section{Thyme (Thymus vulgaris L., Thymi herba)}

Thyme was used by the interviewed farmers to treat ailments of the respiratory tract, gastrointestinal disorders, and metabolic dysfunctions. Farmers in Catalonia use a herbal tea from thyme for treating diarrhoea in calves [8] whereas in Swiss Safiental it is mainly used to treat respiratory tract diseases and to prepare udder ointments [16]. In contrast, no use of thyme has been documented in Austria [6,9,11,13]. In veterinary medicine, thyme preparations are recommended for gastrointestinal diseases, metabolic dysfunctions, and respiratory tract disorders [27]. Thymol and carvacrol are the major constituents of the essential oil $[28,29]$; the bronchodilating properties have been demonstrated with isolated tracheas of guinea pigs [31]. 2 of the 3 daily oral doses recorded in our survey were in the recommended range for oral administrations for humans and animals (table 3) [27, 28], 1 dosage was 20 times higher. 
Linseed (Linum usitatissimum L., Lini semen)

Linseed was administered orally for gastrointestinal disorders, as reported also from Austria and Italy [6, 9, 11, 26]. In addition, farmers in our study used linseed as a poultice for internal injuries. Similar use has been documented in several regions of Austria [9, 13]. Linseed contains mucilaginous polysaccharides which produce a protective and soothing layer on skin and mucous membranes. In veterinary medicine, linseed is used as a mild laxative given either as mucilage or as whole seeds [27]. The dosages administered by the interviewed farmers corresponded with the recommended dosage per kilogram MBW for animals and humans (table 3) $[27,28]$.

\section{Caraway (Carum carvi L., Carvi fructus)}

Caraway was orally administered to treat gastrointestinal disorders and metabolic dysfunctions. No usage of caraway fruit has been documented in surveys conducted in Austria, Italy, and Spain [6-9, 11, 13] but some applications are documented for Swiss Safiental [16]. Veterinary medicine recommends caraway in disorders of the gastrointestinal tract [27]. The essential oil facilitates digestion and has antibacterial and antimycotic properties [32]. Extracts have been shown to exert a spasmolytic effect on smooth muscle cells of guinea pigs [33]. On average, the dosages used by the interviewed farmers were comparatively high (table 3 ) [27, 28].

\section{Stinging Nettle Herb (Urtica dioica L., Urticae herba)}

Stinging nettle was administered as a restorative remedy and was the only herbal drug applied to treat 4 different animal species. In Tuscany, Catalonia, and Northwest Spain, as well as in Swiss Safiental, stinging nettle is reportedly used as restorative remedy and as anti-inflammatory [7, 8, 26]. No usage of stinging nettle has been documented in Austria [6, 9 , $11,13]$. In veterinary medicine, stinging nettle is recommended to increase urinary flow during bacterial and inflammatory diseases of the urinary tract, and as adjuvant treatment in rheumatic complaints. Stinging nettle herb shows mild antihypertensive, analgesic, local anaesthetic, antiphlogistic, antirheumatic, and diuretic properties [27, 28]. On average, the dosages reported by the farmers were higher for pigs and cattle and lower for hens than recommended in veterinary and human medicine; however, doses given to horses were comparable to recommended veterinary and human dosages (table 3 ).

\section{Coffee (Coffea arabica L.)}

The farmers brewed coffee to treat gastrointestinal disorders, metabolic dysfunctions, infertility, and diseases of the female genitalia. In 7 homemade herbal remedies they added schnapps to the coffee. In Austria and Swiss Safiental, the application of coffee, with or without schnapps, was documented for similar traditional uses $[6,9,11,16]$. Coffee beans contain purine alkaloids, mainly caffeine, and theophylline as a minor by-product. Coffee extract can be used to alleviate mental and physical fatigue [34]. In a randomized placebo-controlled, double-blind study, a subcutaneous injection of $10 \mathrm{ml}$ coffee preparation accelerated recovery from diarrhea in $30 \%$ of newborn calves (table 3) [35]. For all coffee preparations, the dosages administered by the farmers were higher than used in the placebo-controlled study, probably due to the different routes of administration [35].

Marigold Flowers (Calendula officinalis L., Calendulae flos) Ointments, tinctures, and infusions prepared from marigold flowers were used to treat wounds and teat lesions. These administrations were also documented in Austria and Swiss Safiental; marigold infusions were also given to treat indigestion $[11,16]$. The antibacterial, antifungal, immunostimulant, and wound healing properties of marigold are exploited in veterinary medicine in the topical treatment of lacerations, contusions, and slow-healing wounds [27].

\section{Comfrey (Symphytum officinale L., Symphyti radix, Symphyti herba)}

The farmers prepared ointments and tinctures from comfrey roots, or used the leaves directly to treat sprains, contusions, swollen joints, or indigestion. Comparable results were found in Swiss Safiental [16]. No usage of comfrey has been documented in Austria [6, 9, 11]. In veterinary medicine, comfrey is used in topical application to treat contusions, sprains, and pulled muscles [27]. Allantoine and hydroxycinnamic acid derivatives are considered to be responsible for the analgesic, antiphlogistic properties of comfrey [29].

\section{Common Buckthorn (Rhamnus catharticus L.)}

The farmers used branches of Rhamnus catharticus L. against cattle ringworm. This kind of treatment has only been documented in Switzerland. Despite lacking scientific data and the fact that the herbs were not administered or applied to the animals but hung up in the stable, this type of use seems to be common, and the farmers were highly satisfied with the results of the treatment.

\section{Conclusion}

The investigated farmers in the Northern part of Switzerland administered a variety of homemade herbal remedies mainly based on plants from the families of Asteraceae, Lamiaceae, and Apiaceae. With few exceptions, categories of use and dosages were comparable with the available literature. In general, the farmers were satisfied with the outcome of the applications. Further studies in other regions of Europe should be carried out to get a closer view on traditional knowledge and use of homemade herbal remedies. 


\section{Acknowledgement}

The authors sincerely thank the organic advisory services of the cantons Zurich, Schaffhausen and Aargau, the 'Schweizerische Medizinische Gesellschaft für Phytotherapie' (SMGP), the Paul Schiller Foundation, the Bristol Foundation (both in Zurich), and the PlantaVet GmbH for financial support of the study.

\section{Disclosure Statement}

The authors declare no conflict of interest.

\section{References}

1 McCorkle CM: An introduction to ethnoveterinary research and development. J Ethnobiol 1986;6:129149

2 WHO: Traditional Medicine. Fact sheet no. 134 2008. www.who.int/mediacentre/factsheets/fs134/en.

3 Anyinam C: Ecology and ethnomedicine: exploring links between current environmental crisis and in digenous medical practices. Soc Sci Med 1995;40: 321-329.

$\checkmark 4$ Pieroni A, Howard P, Volpato G, Santoro RF Natural remedies and nutraceuticals used in ethnoveterinary practices in Inland Southern Italy. Vet Res Commun 2004;28:55-80.

5 Maphosa V, Masika PJ: Ethnoveterinary uses of medicinal plants: a survey of plants used in the ethnoveterinary control of gastro-intestinal parasites of goats in the Eastern Cape Province, South Africa. Pharm Biol 2010;48:697-702.

6 Bizaj M: Lokales Wissen von Osttiroler Bäuerinnen und Bauern über Pflanzen und Hausmittel zur Gesunderhaltung und Krankheitsbehandlung ihrer Tiere und die Bedeutung für den biologischen Landbau. Diplomarbeit an der Universität für Bodenkultur Wien, Institut für ökologischen Landbau, Department für Nachhaltige Agrarsysteme, 2005

7 Blanco E, Macia MJ, Morales R: Medicinal and veterinary plants of El Caurel (Galicia, Northwest Spain). J Ethnopharmacol 1999;65:113-124.

8 Bonet MA, Vallès J: Ethnobotany of Montseny biosphere reserve (Catalonia, Iberian Peninsula): plants used in veterinary medicine. J Ethnopharmacol 2007;110:130-147.

9 Grabowski M: «Meisterwurz und Aderlass». Anwendung und Wandel des ethnoveterinärmedizinischen Wissens im Grossen Walsertal/Voralberg unter Hervorhebung der pflanzlichen Hausmittel und des religiösen Brauchtums. Diplomarbeit an der Universität Wien, 2010.

10 Pieroni A, Guisti ME, de Pasquale C, Lenzarini C, Censorii E, Gonzales-Tejero M, Sanchez-Rojas C, Ramiro-Gutierrez J, Skoula M, Johnson C, Sarpaki A, Della A, Paraskeva-Hadijchambi D, Hadjichambis A, Hmamouchi M, El-Jorhi S, El-Demerdash M, El-Zayat M, Al-Shahaby O, Houmani Z, Scherazed M: Circum-Mediterranean cultural heritage and medicinal plant uses in traditional animal healthcare: a field survey in eight selected areas within the RUBIA project. J Ethnobiol Ethnomed 2006;2:16.
11 Rudolph G: Lokales Erfahrungswissen von Biobäuerinnen und Biobauern in der West- und Südsteiermark über den Einsatz von Pflanzenarten und Hausmitteln in der Tierheilkunde im Vergleich zum Erfahrungswissen von Landwirten in den nördlichen gemässigten Klimazonen. Diplomarbeit an der Universität für Bodenkultur Wien, Institut für ökologischen Landbau, Department für Nachhaltige Agrarsysteme, 2008.

12 Schunko C, Vogl CR: Organic farmers use of wild food plants and fungi in a hilly area in Styria (Austria). J Ethnobiol Ethnomed 2010;6:17.

13 Vogl-Lukasser B, Vogl CR, Bizaj M, Grassner S, Bertsch C: Lokales Erfahrungswissen über Pflanzenarten aus Wildsammlung mit Verwendung in der Fütterung und als Hausmittel in der Volksheilkunde bei landwirtschaftlichen Nutztieren in Osttirol, Projekt gefördert vom Land Tirol und dem Lebensministerium (BM:LFUW), 2006. www.nas. boku.ac.at/fileadmin/_/H93/H933/Personen/ Vogl/1272_VOGL_Wildsammlung03042006.pdf.

14 Vogl-Lukasser B, Vogl CR, Bizaj M, Grasser S: Tierheilkunde mit Hausmitteln. Freiland J 2006;3: 10-11.

15 Scherrer AM, Motti R, Weckerle CS: Traditional plant use in the areas of Monte Vesole and Ascea, Cilento National Park (Campania, Southern Italy). J Ethnopharmacol 2005;97:129-143.

16 Joos B: Lokales Wissen über Gesundheit und Krankheit des Viehs in Graubünden. Diplomarbeit an der Universität für Bodenkultur Wien, Institut für Ökologischen Landbau, Department für Nachhaltige Agrarsysteme, 2010.

17 Council Regulation (EC) no. 834/2007 on Organic Production and Labelling of Organic Products. http://eur-lex.europa.eu/LexUriServ/LexUriServ.do ?uri=OJ:L:2007:189:0001:0023:EN:PDF.

18 Verordnung über die biologische Landwirtschaft und die Kennzeichnung biologisch produzierter Erzeugnisse und Lebensmittel. Stand 1.1.2011. Artikel 16. www.admin.ch/ch/d/sr/910_18/index.html.

19 Tierarzneimittelkompendium der Schweiz. wwwvetpharm.uzh.ch/perldocs/index t.htm.

20 Schweizer Bauernverband. www.sbv-usp.ch/de/ statistik.

21 Bernard HR: Research Methods in Anthropology - Qualitative and Quantitative Approaches, ed 4. Walnut Creek, CA, Altamira Press, 2006.
22 Weller SC, Romney AK: Systematic Data Collection - Qualitative Research Methods Series, volume 10. Thousand Oaks, CA, Sage Publications, 1988, pp 9-20.

23 Microsoft Access database (version 2010). http:// office.microsoft.com/en-us/access/.

24 Löscher W, Ungemach FR, Kroker R: Grundlagen der Pharmakotherapie bei Haus- und Nutztieren, 2. Auflage. Berlin, Paul Parey, 1994, S. 400-401.

25 Zealley AK, Aitken RCB: Measurement of Mood. Proc R Soc Med 1969;62:993-996.

26 Uncini Manganelli RE, Camangi F, Tomei PE: Curing animals with plants: traditional usage in Tuscany (Italy). J Ethnopharmacol 2001;78:171-191.

27 Reichling J, Gachnian-Mirtscheva R, Frater-Schröder M, Saller R, Di Carlo A, Widmaier W: Heilpflanzenkunde für Tierärzte. Berlin, Springer, 2005.

28 ESCOP Monographs, ed 2, completely revised and expanded. Stuttgart, Thieme, 2003.

29 Wichtl M: Teedrogen und Phytopharmaka - ein Handbuch für die Praxis auf wissenschaftlicher Grundlage, 5. Auflage. Stuttgart, Wissenschaftliche Verlagsgesellschaft mbH, 2009

30 Cemek M, Yilmaz E, Büyükokuroglu ME: Protective effect of Matricaria chamomilla on ethanolinduced acute gastric mucosal injury in rats. Pharm Biol 2010;48:757-763.

31 Boskabady MH, Aslani MR, Kiani S: Relexant effect of Thymus vulgaris on guinea-pig tracheal chains and its possible mechanism(s). Phytother Res 2006;20:28-33.

32 Hawrelak JA, Cattley T, Myers SP: Essential oils in the treatment of intestinal dysbiosis: a preliminary in vitro study. Altern Med Rev 2009;14:4.

33 Al-Essa MK, Shafagoj YA, Mohammed FI, Afifi FU: Relaxant effect of ethanol extract of Carum carvi on dispersed intestinal smooth muscle cells of the guinea pig. Pharm Biol 2010;48:76-80.

34 Hiller K, Melzig MF: Die große Enzyklopädie der Arzneipflanzen und Drogen, genehmigte Sonderausgabe. Erfstadt, Area, 2006.

35 Ponepal V, Spielberger U, Riedel-Caspari G, Schmidt FW: Use of a Coffea arabica tosta extract for the prevention and therapy of polyfactorial infectious diseases in newborn calves. Dtsch Tierarztl Wochenschr 1996;103:390-394. 